\title{
AIR QUALITY CONTROL MODEL (DUST PARTICLE) WITH SPRAY TOWER
}

\author{
Hari Rudijanto I.W ${ }^{1)}$, Asep Tata Gunawan ${ }^{2)}$, Zaeni Budiono ${ }^{3)}$ \\ 1,2 )Prodi Sanitasi Lingkungan Program Sarjana Terapan Jurusan Kesehatan Lingkungan, Poltekkes Kemenkes Semarang, Indonesia \\ Corresponndence email : harirudijantoiw@poltekkes-smg.ac.id
}

\begin{abstract}
Introduction:Air is a gas mixture that consists of several components and is spread throughout the area. Air pollution is the presence in the atmosphere in the form of solid particles, liquid droplets or gaseous components abnormally or in the presence in greater concentrations. There is an easy way to control air pollution by reducing the source of the pollution. However, control is part of air health as with the concept of water treatment. The purpose of this study was to design a device to defray the particles of spray tower dust at a low cost. Methods: This type of research used a pre experiment with the aim of testing the Spray Tower tool in reducing the levels of dust particles from the combustion process with coal briquettes, rice husks, and old tires. The pre test was coal briquettes, rice husk ash, and tires without being sprayed with water. The post test were coal, rice husks, and tires with sprayed water (with the help of 1 nozzle, 2 nozzles and 3 nozzles). The independent variable is the number of nozzles sprayed, the dependent variable includes a decrease in the level of dust particles while the disturbing variable consists of sprayed water discharge, weight of coal briquettes, rice husk ash and tires, air temperature, humidity, height of spraying tower, nozzle diameter. Result and discussion: of the study the average air temperature was $20.17 \mathrm{oC}$, humidity was $82 \%$. The water discharge for 1 nozzle is $47.76 \mathrm{ml} / \mathrm{second}$, 2 nozzles are $83.75 \mathrm{ml} /$ second and 3 nozzles are $113.76 \mathrm{ml} /$ second. The initial particle content of old tires was $3,020,000 \mu \mathrm{g} / \mathrm{m} 3$, coal briquettes $(420,000 \mu \mathrm{g} / \mathrm{m} 3)$ and rice husk ash $(110,000 \mu \mathrm{g} / \mathrm{m} 3)$. The average content of used tire dust particles with one nozzle $(1,273.33 .33 \mu \mathrm{g} / \mathrm{m} 3)$, coal briquettes with one nozzle $(361,666.67 \mu \mathrm{g}$ / $\mathrm{m} 3)$ and rice husk with one nozzle $(23,333.33 \mu \mathrm{g} / \mathrm{m} 3)$. The average dust particle content of old tires with two nozzles $(16,666.67 \mu \mathrm{g} / \mathrm{m} 3)$, coal briquettes with two nozzles $(195,000 \mu \mathrm{g} / \mathrm{m} 3)$ and rice husks with two husks $(18,333.33 \mu \mathrm{g} / \mathrm{m} 3)$. The average content of used tire dust particles with three nozzles $(13,333.33 \mu \mathrm{g} / \mathrm{m} 3)$, coal briquettes with three nozzles $(13,333.33 \mu \mathrm{g} / \mathrm{m} 3)$ and rice husks with three husks $(13,333.33 \mu \mathrm{g} / \mathrm{m} 3)$. Conclusion: When compared with Government regulation no. 41 of 1999 is still far from the standard $230 \mu \mathrm{g} /$ $\mathrm{m} 3$ (24 hours), $90 \mu \mathrm{g} / \mathrm{m} 3$ (1 hour). Suggestion It is necessary to conduct other similar studies with a larger sample size, varying air pollution groups, modified models and diameters, controlled gross flow rates.
\end{abstract}

Keywords: Dust particles; spray tower;tires, coal briquettes; rice husk ash 


\section{Introduction}

Air is a gas mixture that consists of many components and is widely distributed. Before the intervention of human activities, the air in the atmosphere could be called normal or clean (BTKL Jakarta, 2004). Air is an important environmental component in human life. Indonesia's health development policy in 2010 is an air pollution control program which is one of the top ten programs (Dit. Pemehatan Lingkungan, 2004).

Common sources of indoor air quality problems (NIOSH, 1997) are lack of ventilation $(52 \%)$, sources of indoor contamination (16\%), contaminants from outdoors $(10 \%)$, microbes $(5 \%)$, building materials (4\%), others (13\%). Household air pollution is mainly due to fuel in the kitchen.

Air pollution is the entry of substances, energy, and or other components into the ambient air by human activities so that the ambient quality drops to a certain level which causes ambient air to not fulfill its function (PP RI No. 41 of 1999). Based on ambient air quality standards (Decree of the Minister of State KLH No. 2/1988), one of the parameters of air pollution is dust.

The use of oil substitute fuels (BBM) such as coal, husk ash as an energy source in the combustion process will have an adverse impact, namely air pollution (dust particles). The use of coal, husk ash, is an alternative substitute for fuel oil (including use in the manufacture of coal) because it is calculated from the use of cheap and efficient energy sources. Naturally, dust particles can be generated from dry soil dust carried by wind or from volcanic vomit. Incomplete combustion of fuel containing carbon compounds (old tires) will cause smoke which is almost entirely composed of pure carbon particles or mixtures with various organic gases. In general, the particle size of about $\Phi 5$ microns is the size of particles in the air that can enter the lungs and settle in the alveoli (BTKL Jakarta, 2004). The size of the dust particles that endanger health 0.1 micron-10 micron causes eye irritation, respiratory system disorders, toxic metals in the dust particulate in the air is the biggest danger to health. If inhaled, the effect is greater than the same dose that comes from food or drink (Dit.Penyehatan Lingkungan, 2004).
The floating dust particles are a very complicated mixture of various organic and inorganic compounds, the largest in the air with very small diameters ranging from $<1$ micron to a maximum of 500 microns (Wiwiek P, 2002). The dust particles will remain in the air for a relatively long time while floating in the air and enter the human body through the respiratory tract, can interfere with the eye's visibility and also carry out various chemical reactions in the air. Dust particles generally contain a variety of different chemical compounds with different sizes and shapes depending on their emission source. The floating dust particles are also produced from the incomplete combustion of coal, husk ash, so that complex aerosols are formed from tar grains. Compared to burning coal, burning oil and gas generally produces less SPM (Suspended Particle Matter).

Control of dust particles in air quality control technology includes cyclone systems, bag filters, spray towers or scrubbers or by using electric precipitators (Vesilind, t.th).

Based on the description above, the researchers are interested in conducting research with the title "Model of Air Quality Control (Dust Particles) with a Spray Tower". The purpose of this research is to design the building of a low cost spray tower dust particle reduction device.

\section{Methods}

This type of research is a pre experiment with the aim of testing the Spray Tower tool in reducing the levels of dust particles from the combustion process with coal briquettes, rice husks, and old tires. The pre test was coal briquettes, rice husk ash, and tires without being sprayed with water. The post test were coal, rice husks, and tires with sprayed water (with the help of 1 nozzle, 2 nozzles and 3 nozzles). The independent variable is the number of nozzles sprayed, the dependent variable includes a decrease in the level of dust particles, while the disturbing variable consists of sprayed water discharge, weight of coal briquettes, rice husk ash and tires, air temperature, humidity, height of spraying tower, nozzle diameter.

In this research, the tools used to collect data were in the form of a set of spray towers consisting of a furnace, GI pipe (6 
inch), PVC pipe (1 inch), bucket, pump, blower, plastic hose, funnel cover, and LVS (Low Air Sampler Volume). The materials used to collect data were coal briquettes, rice husks, old tires, clean water, and fiber glass. The results were analyzed by using paired sample t-test and compared with Government Regulation No. 41 of 1999 concerning Air Pollution Control (230 pg / Nrn3 measurement time for 24 hours), $90 \mu \mathrm{gr} \quad / \quad \mathrm{Nm} 3$ (measurement time for 1 hour).

3. Results and Discussion

1. Measurement of Air Temperature and Air Humidity

Table 1 Measurement Results of Air

Temperature and Air Humidity

Air Humidity

\begin{tabular}{cccc}
\hline No. & $\mathbf{1 0}$ Minutes & $\begin{array}{l}\text { Air } \\
\text { Temp } \\
\text { eratur } \\
\text { e } \\
\left({ }^{\circ} \mathbf{C}\right)\end{array}$ & $\begin{array}{l}\text { Air } \\
\text { Humidity } \\
(\%)\end{array}$ \\
\hline 1. & & 21 & 29,00 \\
2. & II & 22 & 30,00 \\
3. & III & 19 & 30,00 \\
4. & IV & 20 & 30,00 \\
5. & V & 19 & 30,50 \\
6. & VI & 20 & 30,00 \\
\hline \multicolumn{2}{c}{ Average } & 20,17 & 82 \\
\hline
\end{tabular}

Source: Primary Data

2. Measurement of the Discharge of Water Sprayed

Table 2 Measurement Results of Sprayed Water Discharge

\begin{tabular}{clccc}
\hline No. & $\begin{array}{l}\text { Numbe } \\
\text { r of } \\
\text { nozzles }\end{array}$ & $\begin{array}{l}\text { Water } \\
\text { Volume } \\
(\mathbf{m l})\end{array}$ & $\begin{array}{l}\text { Time } \\
\text { (secon } \\
\mathbf{d})\end{array}$ & $\begin{array}{c}\text { Dischar } \\
\text { ge(ml/sec } \\
\text { ond) }\end{array}$ \\
\hline 1. & One (1) & 1000 & 20,94 & 47,76 \\
2. & Two (2) & 1000 & 11,94 & 83,75 \\
3. & Three (3) & 1000 & 8,79 & 113,76 \\
\hline
\end{tabular}

Source: Primary Data

3. Measurement of Dust Particle Levels Table 3 Particle Level Measurement Results Early Dust

\begin{tabular}{|c|c|c|}
\hline No. & Burned Type & $\begin{array}{c}\text { Dust Content } \\
\left(\mu \mathrm{g} / \mathrm{m}^{3}\right)\end{array}$ \\
\hline 1. & Old Tires & $3.020 .000,00$ \\
\hline 2. & Coal Briquettes & $420.000,00$ \\
\hline 3. & Rice Husk & $110.000,00$ \\
\hline
\end{tabular}

Source: Primary Data

Table 4 Particle Level Measurement Results Dust With Variation Nozzle

\begin{tabular}{|c|c|c|c|c|}
\hline \multirow{2}{*}{ No. } & \multirow{2}{*}{$\begin{array}{c}\text { Burned } \\
\text { Type }\end{array}$} & \multicolumn{2}{|c|}{$\begin{array}{l}\text { Number of } \\
\text { Nozzle }\end{array}$} & \multirow[b]{2}{*}{$\begin{array}{l}\text { Three } \\
\left(\mu \mathrm{g} / \mathrm{m}^{3}\right)\end{array}$} \\
\hline & & $\begin{array}{l}\begin{array}{l}\text { One } \\
(\mu \mathrm{g} / \mathrm{m} 3\end{array} \\
)^{-}\end{array}$ & $\begin{array}{c}\text { Two } \\
\left(\mu \mathrm{g} / \mathrm{m}^{3}\right)\end{array}$ & \\
\hline \multirow{6}{*}{1.} & Old Tires & & & \\
\hline & R1 & $2.050 .000,00$ & $35.000,00$ & 5000 \\
\hline & $\mathrm{R} 2$ & $1.340^{\prime} .000,00$ & $10.000,00$ & $10.000,00$ \\
\hline & R3 & $450.000,00$ & $5.000,00$ & $25.000,00$ \\
\hline & Average & $1.273 .333,33$ & $16.666,67$ & $13.333,33$ \\
\hline & $\begin{array}{l}\text { Drop } \\
\text { Efficiency } \\
(\%)\end{array}$ & 57,84 & 99,45 & 99,56 \\
\hline \multirow{6}{*}{2.} & $\begin{array}{l}\text { Briket } \\
\text { Batubara }\end{array}$ & & & \\
\hline & $\mathrm{R} 1$ & $395.000,00$ & $235.000,00$ & $15.000,00$ \\
\hline & $\mathrm{R} 2$ & $370.000,00$ & $210.000,00$ & $20.000,00$ \\
\hline & R3 & $320.000,00$ & $140.000,00$ & $5.000,00$ \\
\hline & Average & $361.666,67$ & $195.000,00$ & $13.333,33$ \\
\hline & $\begin{array}{l}\text { Drop } \\
\text { Efficiency } \\
\text { of }\end{array}$ & 13,89 & 53,57 & 96,83 \\
\hline \multirow{6}{*}{3.} & $\begin{array}{l}\text { Rice } \\
\text { Husk }\end{array}$ & & & \\
\hline & $\mathrm{R} 1$ & $30.000,00$ & $30.000,00$ & $15.000,00$ \\
\hline & $\mathrm{R} 2$ & $15.000,00$ & $5.000,00$ & $15.000,00$ \\
\hline & R3 & $25.000,00$ & $20.000,00$ & $10.000,00$ \\
\hline & $\begin{array}{l}\text { Average of } \\
\text { Drop } \\
\text { Efficiency }\end{array}$ & $23.333,33$ & $18.333,33$ & $13.333,33$ \\
\hline & & 78,79 & 83,33 & 87,88 \\
\hline
\end{tabular}

Sources: Primary Data

4. Paired Samples Test Statistical Analysis

Table 5 Analysis Results Between Types of Treatment

\begin{tabular}{clcc}
\hline No. & $\begin{array}{l}\text { Type of } \\
\text { Treatmen } \\
\mathbf{t}\end{array}$ & Mean & $\begin{array}{c}\text { Sig. } \\
\text { (2 Tailed) }\end{array}$ \\
\hline $\begin{array}{l}\text { Old Tires }- \\
\text { Coal } \\
\text { Brickets }\end{array}$ & 480000 & 0,147
\end{tabular}




\begin{tabular}{|c|c|c|c|}
\hline 2. & $\begin{array}{l}\text { Old Brickets - } \\
\text { Rice Husk }\end{array}$ & 665500 & 0,077 \\
\hline 3. & $\begin{array}{l}\text { Coal } \\
\text { Brickets - } \\
\text { Rice Husk }\end{array}$ & 185500 & 0,003 \\
\hline
\end{tabular}

Source:Primary Data

Table 6 Analysis Results Between Treatments

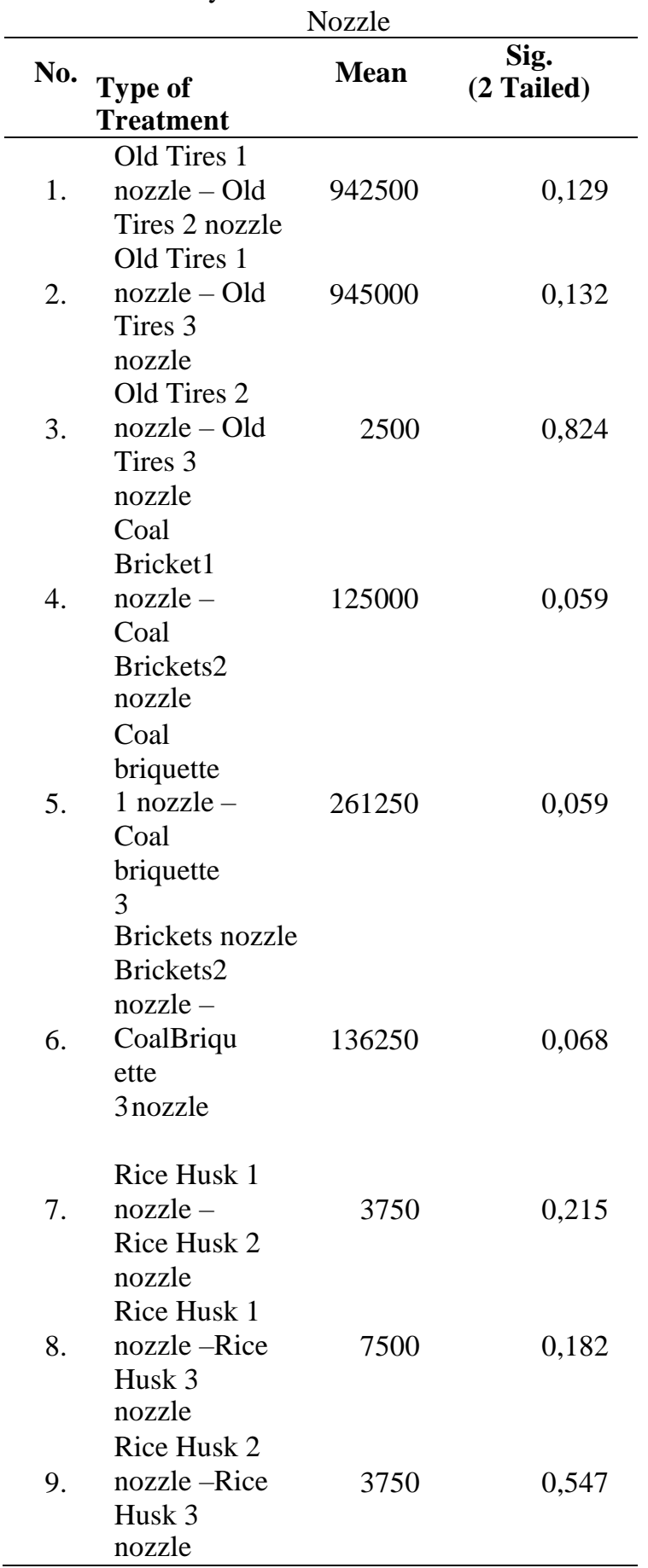

Source: Primary Data
1. Spray Tower

The working principle of the equipment is to clean the dirty air that comes from combustion by spraying water with a nozzle from the top of the tool so that there is contact or a collision between dirty air and water droplets falling down the room with the gravity of the earth while the air flow is net rises to the top of the tower (Crawford, M, 1976). In general, the level of efficiency depends on the contact of air and water, along with the diameter of the size of the gas or water droplets that fall from the nozzle (Vesilind, $t$, th).

2. Nozzle diameter

The diameter of the nozzle indirectly affects the contact between dirty air and water. The smaller the nozzle diameter, the greater the surface area of the liquid in trapping dust particles flying in dirty air. The nozzle diameter used in this study is 2.00 $\mathrm{mm}$ with a dropping velocity in standard air with an amount of $7.07 \mathrm{~m}$ / s (Crawford, M, 1976). The defensive force of water when the liquid is sprayed is $\mathrm{F}=5135 \mathrm{D} 35135$ $\mathrm{x} 0.15243=18.175876 \mathrm{~N}$.

3. Weight of Media Burned The weight or amount of media that is burned will directly affect how much dirty gas or air is released from the furnace. The dirty air flow will depend on the light weight of the media being burned so that it will affect the contact with the water points and the relative velocity between the air and the number of droplets in the spray tower space at one time, as follows:

$\mathrm{V}=\operatorname{Re} \mathrm{v}=912 \times 1.55 \times 10-5 \mathrm{~m} 2 / \mathrm{s}=$ $0.0927 \mathrm{~m} / \mathrm{s}$ D $15.24 \mathrm{~cm} \times 10-2 \mathrm{~m}$

4. Water Discharge

The required water discharge is related to the amount of water sprayed by the nozzle to be able to come into contact with dirty air. Based on table 4.2 , it shows that one nozzle releases $47.76 \mathrm{ml} /$ second of water, two nozzles with a discharge size of 83.75 $\mathrm{ml} /$ second and 3 nozzles with 113.76 $\mathrm{ml} /$ second. Researchers analyzed that there is a tendency that the more the nozzle is opened, the greater the flow of water, so that the contact 
between dirty air and water is greater and the area of the contact surface. This result shows that there is a significant decrease in the level of dust particles (old tires, coal briquettes and rice husk ash).

5. Air temperature and humidity. Physical environment has a role in countering air pollution control even though the amount is not as big as expected.

Based on table 1, the trend of air temperature varies between. $20^{\circ} \mathrm{C}$ and $19^{\circ} \mathrm{C}$ with an average of $20.17^{\circ}$ C. This indicates that the air temperature condition in the research location is quite cold considering that it is in the tourist area of Baturraden (mountains). The effect of air temperature on the degree of daily heat (Q) (Stem, Arthur C, 1976) calculated by $\mathrm{Q}=65 \mathrm{~T}-\mathrm{T}$. (average air temperature) so that $\mathrm{Q}=65 \mathrm{~F}$ $68.31 \mathrm{~T}$ is $-3.3^{\circ} \mathrm{F}$. Temperature $-3.3^{\circ}$ $\mathrm{F}$ means that the air is said to be stable because there is a decrease of less than $1^{\circ} \mathrm{C}$ which is called Subadiabatic (Vesilind, t.th).

Humidity shows an average of $82 \%$. It can be said that the research location contains water points because it is located in a rainy (mountainous) area.

6. Water Pump Power

Dirty air needs to have pressure or pump the air needed so that during combustion there can be contact or a faster collision between dirty air and water so that the process of attaching water droplets to gas particles (dirty air) can be more complete. The amount of energy required can be calculated as follows (Crawford, M, 1976), $\mathrm{W}=5.135 \mathrm{xp}$ air $\mathrm{x}$ D3 $\mathrm{x}$ Voo $\mathrm{x}$ $\mathrm{N}+\mathrm{QAP}=5.135 \times 1000 \mathrm{~kg} / \mathrm{m} 3 \mathrm{x}$ $0.003539 \mathrm{mx} 0.0927 \mathrm{~m} / \mathrm{sx} 0.044+0$ , 00008176 max

$10.79 / \mathrm{m} 2=1.69 \mathrm{~kW}$

7. The height of the spray tower

The higher the spray tower, the more efficient it is in reducing the level of dust particles because there is a wider and longer space so that the contact time between dirty air and water is longer. In addition, the longer the water droplets fall to the bottom of the space and the relative velocity between the water droplets and the air the longer it is expected that the collision between dirty air and water will increase the area of the impact surface.

8. Decreased levels of dust particles Based on table 3, the researcher can analyze that there are differences between old tires, coal briquettes and rice husks based on the level of dust particles if the treatment is not done using water injection. The dust particle content for old tires was $3,020,000.00 \mu \mathrm{g} / \mathrm{m} 3$, the largest compared to coal briquettes $(420,000.00 \mu \mathrm{g} / \mathrm{m} 3)$ and rice husk ash $(110,000.00 \mu \mathrm{g} / \mathrm{m} 3)$. This shows that old tires contain a lot of hydrocarbons (HC). It is characterized by a fiberglass filter filled with black soot. The HC element in the air is a relatively low toxicity and hydrocarbon contains hydrogen and carbon components and is a class of organic components.

(Stern, Arthur C, 1976). However, when carrying out a reaction under sunlight it will form photochemical oxidants which can cause inflammation of the airway and make the material runny (Soedjono et al, 1991). The rubber (tire) industry uses carbon black because it can increase rubber resistance to wear and corrosion. (Siswanto, 1991).

Coal briquettes are materials that contain a compound, sulfur dioxide (SO2). SO2 compounds in the air have a direct influence on humans mainly because of the irritating nature of the gas itself. More than $95 \%$ of the high levels of $\mathrm{SO} 2$ inhaled through the breath will be absorbed by the upper part of the respiratory tract, the percentage will decrease to $50 \%$ for the lower SO2 level of 0.1 ppm. Because it can be annoying. respiration, $\mathrm{SO} 2$ can make bronchitis sufferers and other respiratory tract sufferers become more parchy (BTKL, 2004). Rice husk also contains HC compounds as well, however, because it is a rice plant so it is easily decomposed by the heat of the sun and will naturally decrease by itself.

Based on table 4, there is a significant difference between the use of one nozzle, two nozzle and three nozzles 
in reducing the levels of dust particles (old tires, coal briquettes and rice husks). For one nozzle there was a decrease in the levels of used tire dust particles $(57.84 \%)$, coal briquettes (13.89\%) and rice husk ash (78.79\%). For the two nozzles there was a tendency to have a greater decrease, namely old tires $(99.45 \%)$, coal briquettes, $(53.57 \%)$ and rice husk ash $(83.33 \%)$, while 3 nozzles reduced the level of dust particles as large as old tires. (99.56\%), coal briquettes $(96.83 \%)$ and rice husk ash $(87.88 \%)$.

When analyzed using statistical test paired samples test showed a difference. Table 5 decreased levels of dust particles between old tires and coal briquettes by 0.147 and old tires with rice husk ash by 0.077 , when compared to the value of a $(5 \%)$ there is no significant difference because it exceeds the value of 0.05 . The decrease in the level of dust particles between coal briquettes and rice husk ash is 0.003 , when compared to the value of a $(5 \%)$ there is a significant difference because it is smaller than 0.05 . Researchers analyzed that there was a significant difference between coal briquettes and rice husk ash due to the small difference between the initial dust particle content between coal briquettes $(420,000 \mu \mathrm{g} / \mathrm{m} 3)$ and rice husk ash $(110,000 \mu \mathrm{g} / \mathrm{m} 3)$. In addition, coal briquettes and rice husk ash contain less hydrochloric compounds, carbon (HC) than tires. Based on table 6, there is no significant difference in the reduction in the level of dust particles for old tires, coal briquettes and rice husk ash both for the treatment of various nozzle numbers because they exceed the a value (5\%). Researchers analyzed that the three nozzles were not optimal in reducing the levels of dust particles so that the turnover between the dirty air flow and the water jets did not bond tightly in the spray tower so that the process of attaching water grains to dust particles was imperfect.

\section{Conclusion}

1. Conclusion

The initial dust particle content for old tires is $3,020,000 \mu \mathrm{g} / \mathrm{m} 3$, coal briquette is $420,000 \mu \mathrm{g} / \mathrm{m} 3$ and rice husk ash is $110,000 \mu \mathrm{g} / \mathrm{m} 3$. The particle content of old tires with one nozzle was $1,273.33 .33 \mu \mathrm{g} / \mathrm{m} 3$, coal briquettes with one nozzle were $361,666.67 \mu \mathrm{g} / \mathrm{m} 3$ and rice husks with one nozzle were $23,333.33 \mu \mathrm{g} /$ $\mathrm{m} 3$. The particle content of old tires with two nozzles was $16,666.67 \mu \mathrm{g}$ / $\mathrm{m} 3$, coal briquettes with two nozzles was $195,000 \mu \mathrm{g} / \mathrm{m} 3$ and rice husks with two husks were $18,333.33 \mu \mathrm{g} /$ $\mathrm{m} 3$. The particle content of old tires with three nozzles was $13,333.33 \mu \mathrm{g} /$ $\mathrm{m} 3$, coal briquettes with three nozzles were 13,333.33 $\mu \mathrm{g} / \mathrm{m} 3$ and rice husks with three husks were 13,333.33 $\mu \mathrm{g} / \mathrm{m} 3$. The effectiveness level of the spray tower tool in reducing the levels of dust particles for old tires is 1 nozzle $(57.84 \%), 2$ nozzles $(99.45 \%)$ and 3 nozzles $(99.56 \%)$, for coal briquettes 1 nozzle (13.89\%) ), 2 nozzles (53.57\%) and 3 nozzles $(96.83 \%)$, for rice husks 1 nozzle $(78.79 \%), 2$ nozzle $(83.33 \%)$ and 3 nozzles $(87.88 \%)$. When compared with Government regulation no. 41 of 1999 is still far from the standard $230 \mu \mathrm{g} / \mathrm{m} 3$ (24 hours), $90 \mu \mathrm{g} / \mathrm{m} 3$ (1 hour) is still far from the recommended threshold value (NAV).

2. Suggestion

It is necessary to carry out other research with a larger number of samples and a more varied group of air pollutants.

Another research needs to be conducted with a modification of the model or the various nozzle positions and the number and diameter of the nozzles more.It is necessary to carry out other research with a larger modification of the diameter and height of the tool, the means of controlling the gross air flow rate.

\section{Acknowlegdement}

To be grateful to Alloh, researchers have finished to conduct this research. The researchers deliver many thanks to the Director of Poltekkes Semarang, the Head of Environmental Health Department of Purwokerto, Workshop Staff of Environmental Health Department and the team of researchers. 


\section{References}

Arthur C. Stren, 1976, Air Pollition Thir Edition Volume I, Academy Press New York.

Balai Teknik Kesehatan Lingkungan, 2004, Teknik Pengambilan Sampel, Jakarta.

Departemen Kesehatan R.I, 1999, Petunjuk Pengukuran Kualitas Udara, Dirjen P2MPLP, Jakarta.

Fajar Hadi \& M.Nasroen Riva'i, 1980, Ilmu Teknik Penyehatan 2, Departemen Pendidikan dan Kebudayaan, Jakarta.

Martin Crawford, 1976, Air Pollution Control Theory, Mc Grawhill book Company, New York.

P. Aarne Vesilind, t.th, Environmental Engineering, Duke University, Boston.

Peraturan Pemerintah R.I No. 41 Tahun 1999 Tentang Pengendalian Pencemaran Udara, Jakarta.

Siswanto, 1991, Toksikologi Industri, Balai Hiperkes dan Keselamatan Kerja Jawa Timur, Departemen Tenaga Kerja.

Soedjono, J.A Syarkawi, V. Supriyatno, Nyoman Suendra Titiek Susilorini, Zainal Abidin, Kodma Aladis, Amanto Rahardjo, Djasio Sanropie, Heru Turdja'i, Soemini AR, Nina Marlina, Susilawati, Indarwati, 1991, pedoman Bidang Study Pengawasan Pencemaran Lingkungan Fisik Pada Institusi Pendidikan Tenaka Kesehatan Lingkungan, Departemen Kesehatan R.I, Jakarta.

Tjokrokusumo, 1988, Pengantar Engineering Lingkungan, STTL Yogyakarta. 